\title{
Pengembangan Wahana Edukasi Rainbow Waterfall Salah Satu Spot Iconic Peningkatan Ekonomi Masyarakat Dibumi Perkemahan Bedengan
}

\author{
Markus Diantoro ${ }^{1 *}$, Nasikhudin ${ }^{2}$, Chusnana Insjaf Yogihati ${ }^{3}$, Ishmah Luthfiyah ${ }^{4}$, \\ Nadiya Ayu Astarini ${ }^{5}$ \\ 1,2,3,4,5Universitas Negeri Malang , Jl. Semarang 5 Malang \\ e-mail: markus.diantoro.fmipa@um.ac.id1', nasikhudin.fmipa@um.ac.id² \\ chusnana.insjaf.fmipa@um.ac.id ${ }^{3}$, fiyaishmah99@gmail.com ${ }^{4}$, nadiyaayu24@gmail.com $^{5}$ \\ * Penulis Korespondensi: E-mail: markus.diantoro.fmipa@um.ac.id
}

\begin{abstract}
Bedengan Campsite is one of the Perhutani areas in Selokerto Hamlet, Selorejo Village, Dau District, Malang Regency. Selorejo Village has an area of 39.5 ha for settlements, 410,476 ha for agricultural areas, fields, and livestock crops, 2068.1 ha for the forest area surrounding the village, and 26.6 ha for office development areas and recreational facilities. Bumi Perkemahan Bedengan is one of the tourist destinations in Selorejo. There are several flaws in the Bendengan Campsite: the location is not strategic, it's far away from the center of the city, lack of publicity and iconic spot facilities. Those flaws cause Bendengan Campsite get less attention. A solution that can be done to increase visitors' interest is to create an installation of Rainbow Water Fall Ride as one of the educational iconic photo spot, which is used in the implementation of physical phenomena. Rainbow WaterFall is an educational vehicle by forming a rainbow due to the refraction of sunlight as it passes through the water droplets formed by the nozzle curtain and can turn on the RGB Flood Light at night.
\end{abstract}

Keywords: Dedication society, iconic spots rainbow waterfall, bedengan campsite

\begin{abstract}
Abstrak
Bumi Perkemahan Bedengan merupakan salah satu kawasan perhutani di Dusun Selokerto, Desa Selorejo, Kecamatan Dau, Kabupaten Malang. Desa Selorejo memiliki luas 39,5 ha untuk pemukiman, 410,476 ha untuk area pertanian, ladang, serta tanaman ternak, 2068,1 ha untuk area hutan yang mengelilingi desa, dan 26,6 ha untuk area pengembangan perkantoran dan sarana rekreasi. Bumi perkemahan Bedengan merupakan salah satu destinasi wisata di Selorejo Kekurangan dari bumi perkemahan Bedengan yaitu lokasinya yang jauh dari pusat kota, tidak strategis, publikasi yang kurang, serta kurangnya fasilitas lain seperti spot iconic bumi perkemahan bedengan. Hal menyebabkan bumi perkemahan Bedengan kurang diperhatikan. Solusi yang mampu dilakukan untuk meningkatkan ketertarikan terhadap bumi perkemahan bedengan yaitu dengan membuat instalasi wahana Rainbow Water Fall sebagai salah satu wahana spot iconic foto sarana edukasi yang digunakan dengan penerapan fenomena fisika. Rainbow WaterFall merupakan wahana edukasi dengan membentuk pelangi akibat pembiasan cahaya matahari saat melewati butiran airyang dibentuk oleh nozzle curtain dan mampu menyalakan lampu sorot RGB Flood Light pada malam hari.
\end{abstract}

Kata Kunci: Pengabdian masyarakat, spot iconic rainbow waterfall, Bumi Perkemahan Bedengan

\section{PENDAHULUAN}

Bumi Perkemahan Bedengan merupakan salah satu destinasi wisata yang berlokasi di Dusun Selokerto, Desa Selorejo, Kecamatan Dau, Kabupaten Malang. Lokasi ini terbilang terpencil sebab jarak dari pusat kota yaitu 25 kilometer. Desa Selorejo merupakan desa yang memiliki potensi besar dalam hal agrowisata. Secara astronomis, Desa Selorejo berada pada 756'19.70” LS dan 112.65 BT (“Dau, Malang," 2019). Desa Selorejo tergolong dataran 
tinggi yang memiliki kettinggian 800-1200 dpl (dari permukaan laut) dengan luas perbukitan 333,76 ha. Desa Selorejo merupakan daerah pegunungan dengan tingkat curah hujan $\pm 100 \mathrm{~mm} /$ tahun. Luas hutan 2068,1 ha yang tersebar mengelilingi desa Selorejo. Luas area perkantoran dan sarana rekreasi seluas 26,6 ha. Luas pemukiman $\pm 39,5$ ha dan luas area pertanian 410,47 ha terdiri dari tanah pertanian, ladang, serta peternakan. Desa Selorejo memiliki potensi sebagai wisata petik jeruk dan akan terus dikembangkan untuk menjadi ikon desa. Selain wisata petik jeruk, wisata lainnya yaitu taman wisata Selorejo dan bumi perkemahan Bedengan ("Dau, Malang," 2019). Bumi perkemahan Bedengan sebelumnya merupakan kawasan hutan Perhutani yang digunakan sebagai tempat pembibitan pohon dan tanaman. Berbagai benih ditanam di daerah ini mulai dari pohon durian, jeruk, rambutan, maupun tumbuhan keras lainnya. Pepohonan pinus yang masih lebat memenuhi area Bedengan membuatnya terlihat begitu asri dan sejuk (Kompasiana, 2010). Selain pepohonan, di daerah tepi Bedengan juga terdapat aliran sungai yang mengalir dari air terjun Brues.

Beberapa kekurangan dari bumi perkemahan Bedengan yaitu lokasinya yang jauh dari pusat kota dan tidak strategis, publikasi yang kurang, serta kurangnya fasilitas lain sepeti spot foto dan dikarenakan letak dari coban brush yang sangat jauh. Hal menyebabkan bumi perkemahan Bedengan kurang diperhatikan. Solusi umum guna menjaga kontinuitas berjalannya wisata bumi perkemahan Bedengan yaitu dengan membuat pengadaan instalasi wahana baru yaitu rainbow waterfall sebagai salah satu wahan spot foto dengan background air terjun (Rudi, 2020) .Wahana rainbow waterfall merupakan salah satu bentuk peningkatan ketertarikan terhadap perkemahan Bedengan sehingga mampu meningkatkan kunjungan . Penggunaan pelangi menjadi salah spot iconic ditunjukkan dari tingginya ketertarikan masyarakat dengan pengembangan wisata desa seperti pada tanjung pinang dan pengembangan desa wonosari sebagai kampung pelangi (Erfan Hartono, Dian Prima Safitri, 2019; Irwandi, Sabana, Kusmara, \& Sanjaya, 2020). Hal ini dirasa cocok karena dapat mendukung kegiatan perkemahan yang dilakukan di bumi perkemahan Bedengan.

Wahana rainbow waterfall merupakan salah satu sarana edukasi yang digunakan dengan penerapan Fenomena Fisika. Rainbow waterfall merupakan wahana edukasi dengan membentuk pelangi akibat pembiasan cahaya matahari saat melewati butiran air, lalu cahaya mengalami pembelokan sehingga penyebaran terjadi. Karena air memiliki kepadatan yang lebih tinggi dari udara, cahaya yang melewati butir air akan mengalami perlambatan dan perubahan sudut datang. Fenomena ini dikenal sebagai pembiasan atau refraction (Etminan, 2005; Mihas, 2008). Cahaya matahari sendiri terdiri dari berbagai spektrum cahaya yang berinteraksi secara berbeda-beda terhadap fenomena pembiasan. Oleh karena itu, ketika mengenai butiran air, cahaya matahari akan terpecah menjadi beberapa warna. Perbedaan warna ini disebabkan oleh perbedaan sudut keluar dari tiaptiap gelombang warna tersebut. Gelombang pendek seperti biru dan ungu akan memiliki perubahan sudut yang lebih tinggi dibandingkan dengan gelombang panjang seperti warna merah (Brahman, 2019). Hal inilah yang menyebabkan warna biru selalu berada di bawah dan warna merah selalu berada di atas pelangi. Jika sudut datang sinar matahari tepat, biasanya terletak pada sudut 42 derajat maka, akan terjadi pantulan internal di dalam butir air (Amalia, 2018). Sehingga, pada siang hari merupakan waktu yang tepat dalam membentuk pelangi.

\section{METODE PELAKSANAAN}

Metode didekati dengan menggunakan metode survei-eksperimen dan pelatihan agar lebih efektif dan efisien dalam mencapai target luaran (Hadiningrat, 2020). Tahap awal dilakukan dengan observasi yang bertujuan untuk menganalisis kebutuhan dan permasalahan berdasarkan situasi pada lokasi pengabdian. Tim melakukan kunjungan, 
pengecekan dan dokumentasi serta wawancara ekslusif dengan mitra. Tahap kedua dilakukan perencanaan rancang bangun set Rainbow Waterfall sesuai dengan Gambar 1.
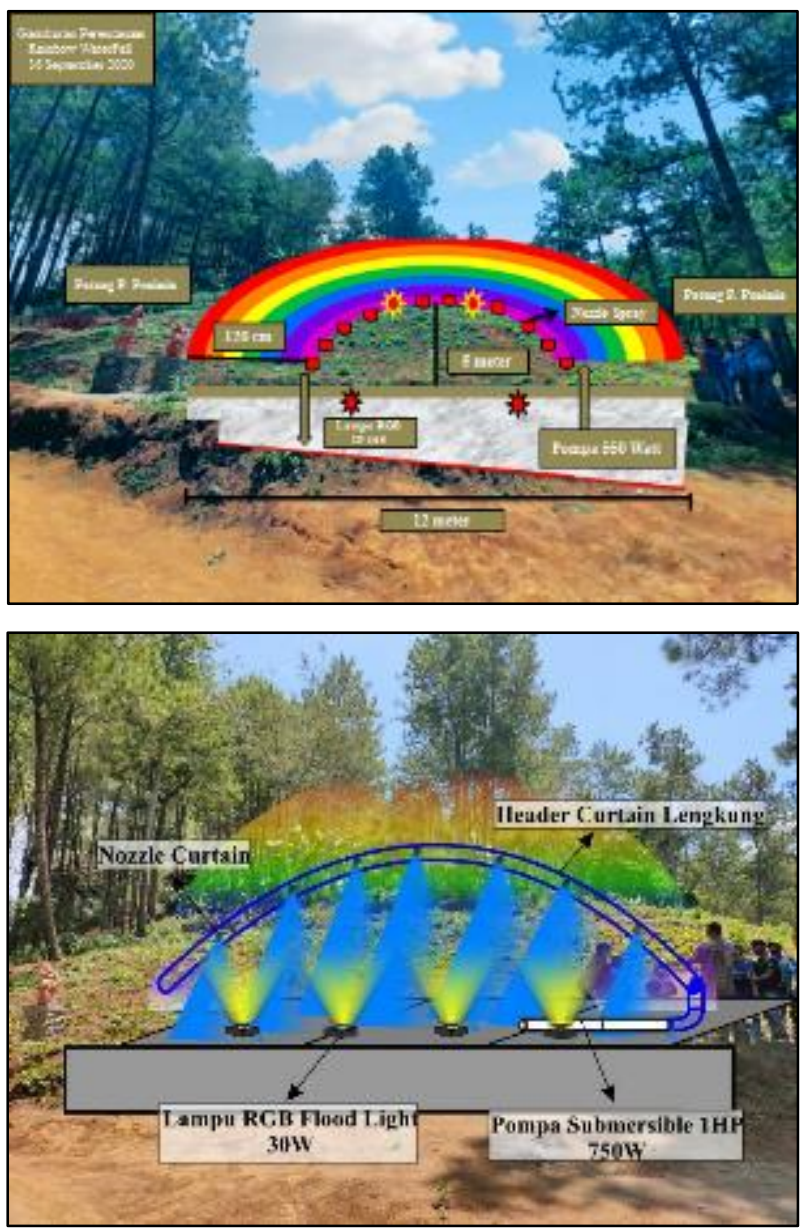

Gambar 1. Desain dan Rancang Bangun Set Rainbow Watefall a) Konstruksi Rainbow WaterFall dan b) Instalasi Teknologi Rainbow WaterFall

Instalasi Rainbow waterfall kegiatan ini dilakukan dengan pembuatan konstruksi kolam, rainbow, nozzle dan header curtain secara langsung di lokasi. Tahap selanjutnya yakni, pengujian performa. Performa sistem diuji untuk mempertimbangkan set Rainbow Waterfall dapat digunakan atau tidak. Serah terima produk. Serah terima produk Rainbow Waterfall dilakukan oleh ketua tim bersama anggota kepada perwakilan pengelola Bumi Perkemahan Bedengan.

\section{HASIL dan PEMBAHASAN}

Observasi awal dilakukan untuk melakukan studi lapangan pembahasan peleletakkan pembangunan spot iconic rainbow waterfall berdasarkan situasi lokasi pengabdian sesuai arahan tim tata letak. Tim tata letak diperlukan untuk memetakan berbagai konstruksi yang akan dibangun kedepannya dan dilakukan pendampingan oleh penanggung jawab bumi perkemahan bedengan sesuai dengan Gambar 2. 


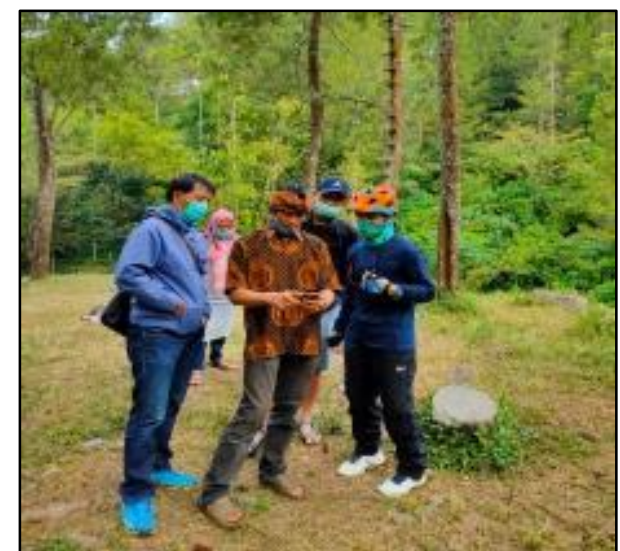

(a)

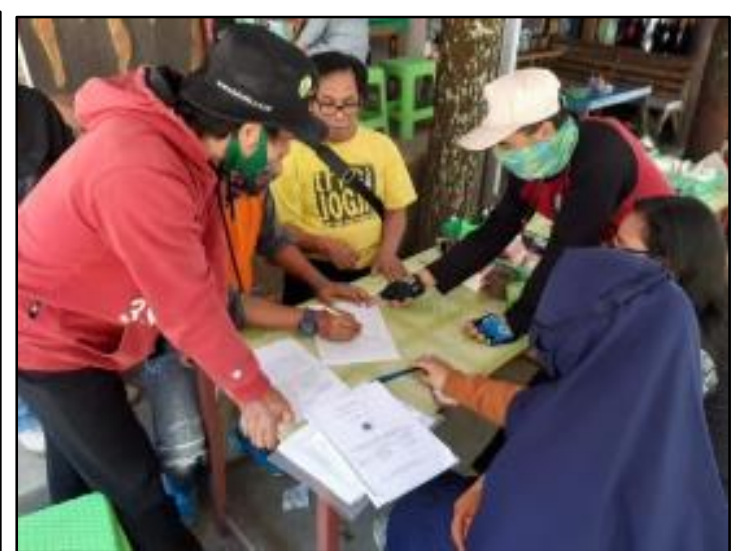

(b)

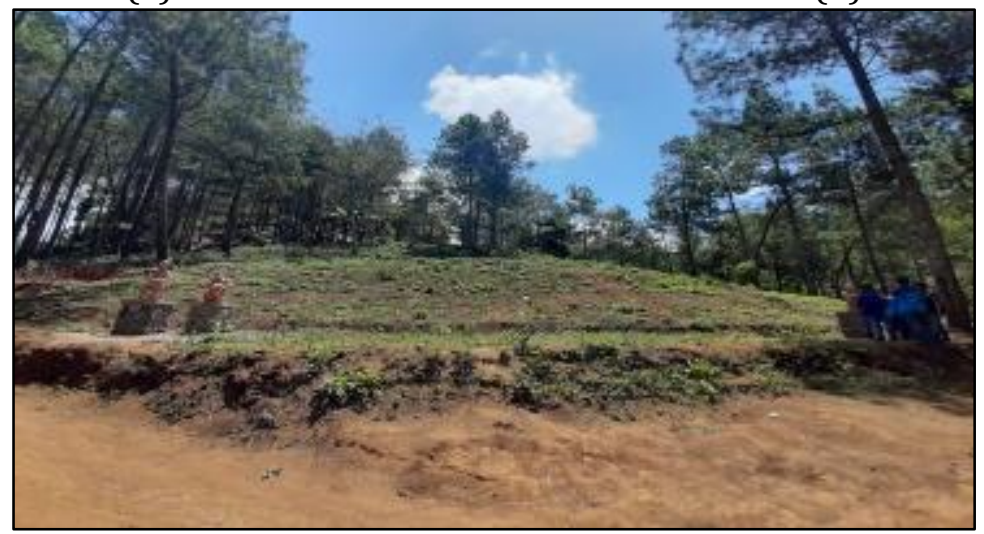

(c)

Gambar 2. (a),(b) Pembahasan Peletakan Spot Iconic Rainbow WaterFall bersama penanggung jawab Bedengan, tim tata letak dan (c) Lokasi Peletakkan Spot Iconic Rainbow WaterFall

Setelah dilakukan studi lapangan menentukan lokasi peletakkan spot iconic rainbow waterfall diperlukan pembahasan keberlanjutan mengenai pembangunan konstruksi dan instalasi rainbow waterfall bersama mitra kepala proyek PT Alfan Mechatronics Innovation untuk pengadaan instalasi rainbow waterfall dengan teknologi nozzle water curtain, lampu sorot RGB dan pompa submersible $1 \mathrm{Hp}$ (750W).

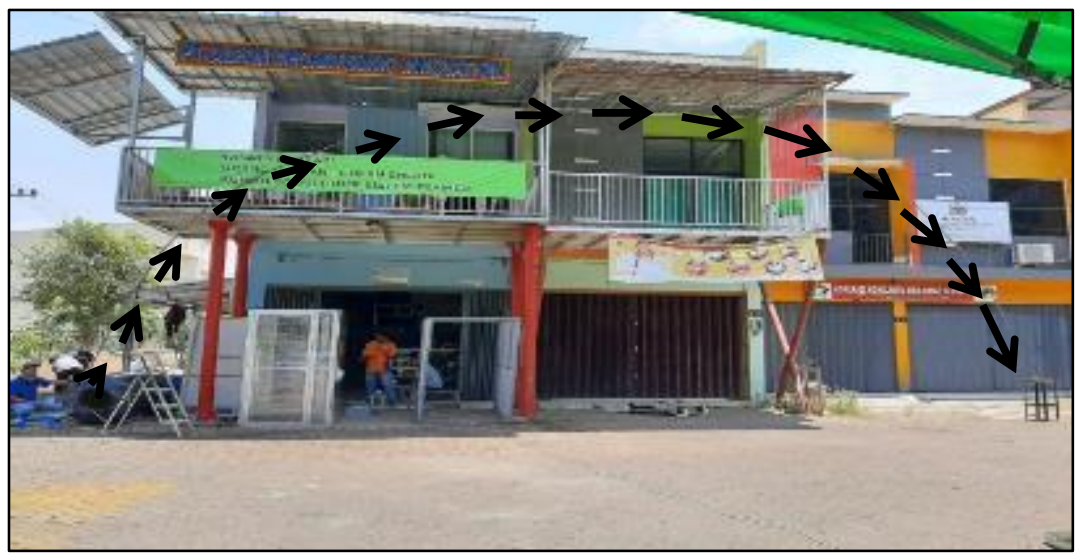

(a) 


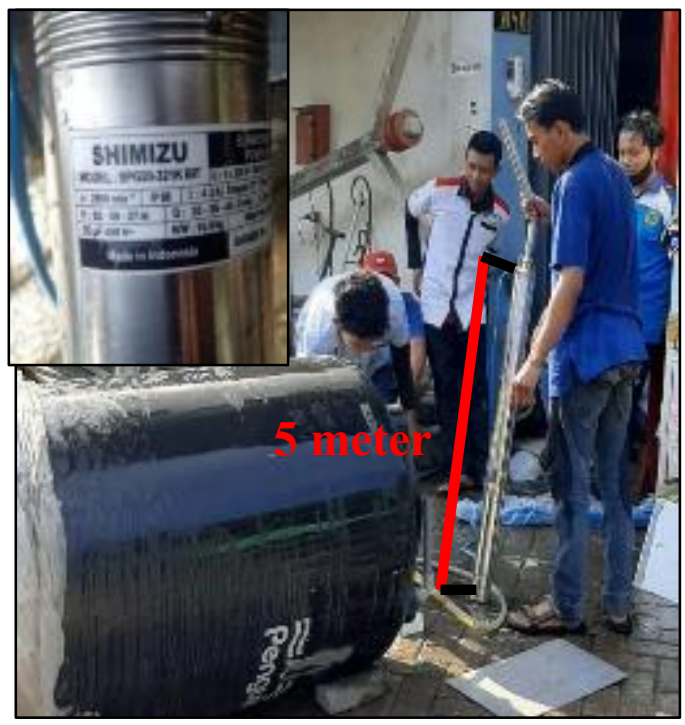

(b)

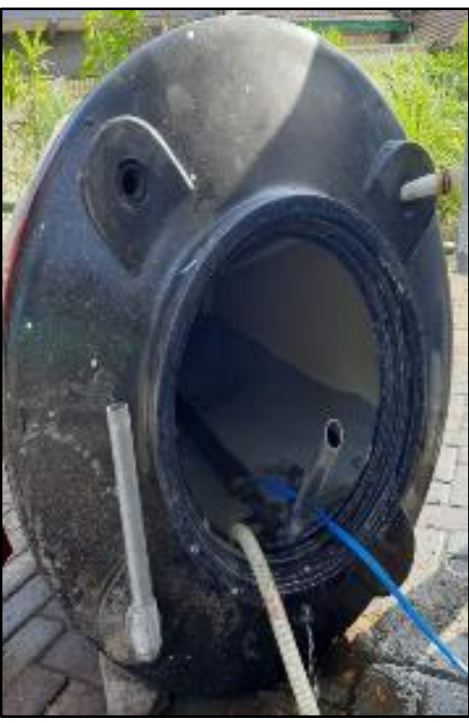

(c)

Gambar 3. (a) Instalasi nozzle curtain dan header curtain lengkung rainbow waterfall ,(b) dan (c) Percobaan pompa submersible Anggota Mahasiswa dan Teknisi PT. Alfan

Mechatronics Innovation

Gambar 3 menunjukkan bahwa percobaan instalasi nozzle curtain dan header curtain lengkung rainbow waterfall Observasi Lanjutan dilakukan dengan diskusi antara anggota mahasiswa dan Bapak Alfan selaku direktur PT. Alfan Mechatronics Innovation untuk pengadaan instalasi rainbow waterfall dengan teknologi Nozzle Water Curtain, Lampu Sorot RGB dan Pompa Submersible $1 \mathrm{Hp}(750 \mathrm{~W})$. Pengujian performa nozzle water curtain dengan pompa submersible dan lampu sorot RGB untuk pengadaan rainbow waterfall.

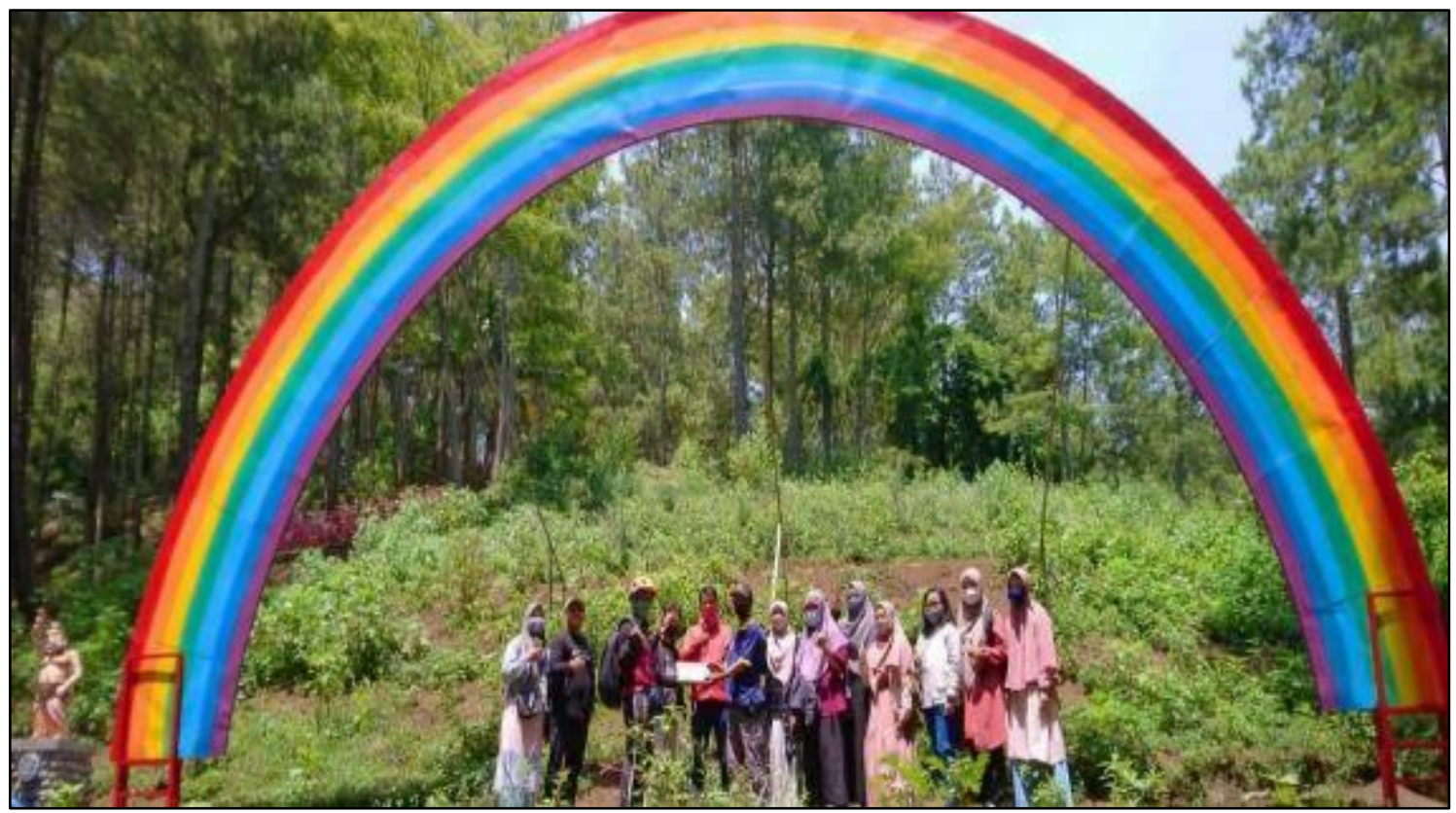

(a) 


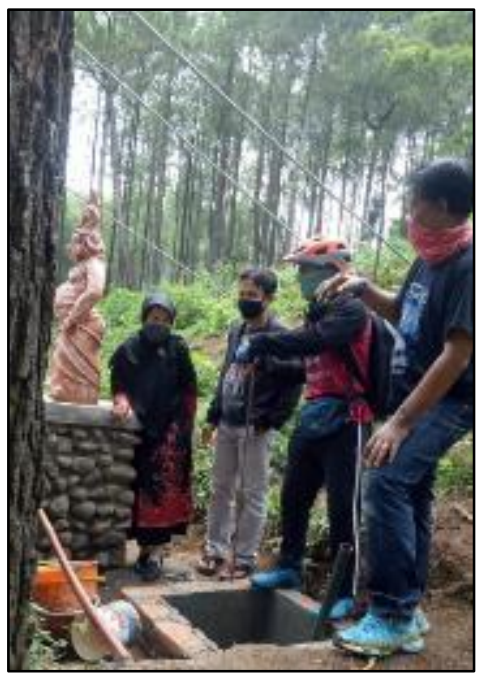

(b)

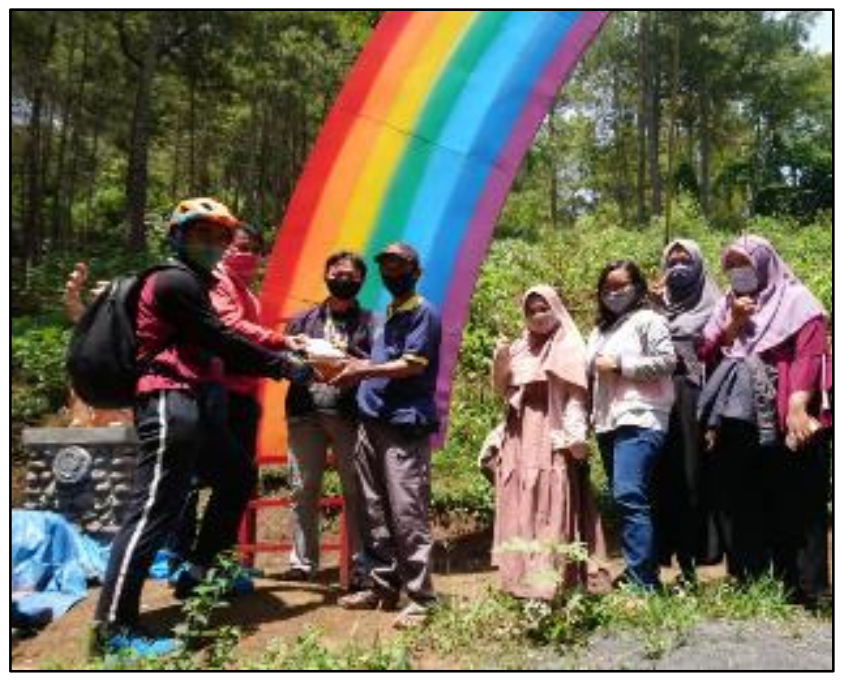

(c)

Gambar 4. a), b) dan c) Penyerahan secara simbolik Spot Iconic Rainbow WaterFall Ketua Pengabdian Universitas Negeri Malang kepada Penanggung Jawab Bumi Perkemahan Bedengan

Proses Penyerahan secara simbolik spot iconic rainbow waterfall kepada penanggung jawab bumi perkemahan bedengan. Proyek pembangunan dlakukan dengan bantuan para penduduk sehingga mampu meningkatkan perekonomian disekitar bumi perkemahan bedengan.

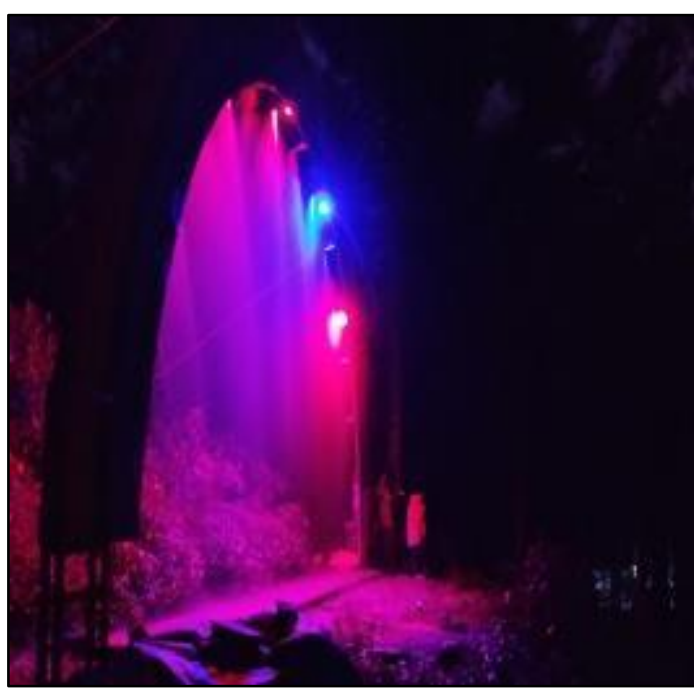

(a)

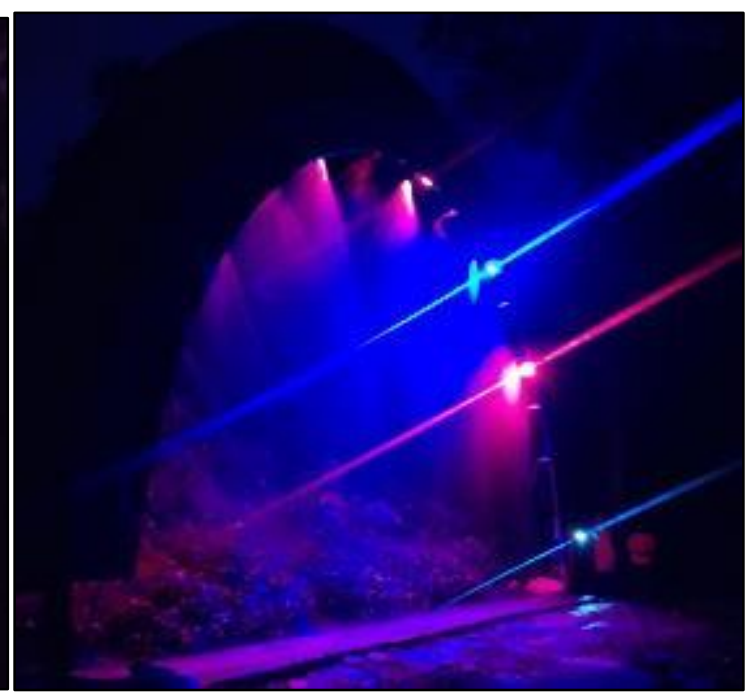

(b)

Gambar 5. a) dan b) Instalasi Spot Iconic Rainbow WaterFall Universitas Negeri Malang dengan performa RGB IP 165 dan Nozzle Curtain Pada Malam Hari

Gambar 5 menunjukkan performa yang baik dengan kombinasi antara lampu flood light RGB IP 165 dan Nozzle Curtain yang baik sehingga memunculkan suasana yang indah sebagai spot iconic. Sedangkan pada siang hari sesua dengan gambar 4 menunjukkan eye catching yang mampu menarik perhatian para wisatawan. Dengan adanya spot iconic ini 
pada siang dan malam hari diharapkan mampu meningkatkan ketertarikan para wisatawan dalam mengunjungi wahana edukasi rainbow water fall.

\section{KESIMPULAN}

Berdasarkan hasil kegiatan pengabdian kepada masyarakat yang telah dilaksanakan dapat disimpulkan penambahan wahana edukasi rainbow waterfall mampu meningkatkan ketertarikan terhadap bumi perkemahan bedengan. Rainbow WaterFall merupakan wahana edukasi dengan membentuk pelangi akibat pembiasan cahaya matahari saat melewati butiran airyang dibentuk oleh nozzle curtain dan mampu menyalakan lampu sorot RGB Flood Light pada malam hari.

\section{UCAPAN TERIMAKASIH}

Ucapan terima kasih kami sampaikan kepada LKDPH Wonorejo Lestari dan Pendanaan PNBP Universitas Negeri Malang serta kepada PT. Alfan Mechatronics Innovation.

\section{DAFTAR PUSTAKA}

Amalia, F. Z. (2018). CAHAYA MENGGUNAKAN CERTAINTY OF RESPONS INDEX ( CRI ) PADA KELAS V DI SDN GUNUNGJATI 1 CAHAYA MENGGUNAKAN CERTAINTY OF RESPONS INDEX ( CRI ) PADA KELAS V DI SDN GUNUNGJATI 1. Central Library of Maulana Malik Ibrahim State Islamic University Of Malang, 1-127.

Brahman, M. A. (2019). Monisme :pengetahuan yang membawa kebijaksanaan. SPHATIKA, $X(1), 1-9$.

Dau, Malang. (2019).

Erfan Hartono, Dian Prima Safitri, K. F. (2019). Peran Pemerintah Daerah Dalam Membangun City Branding di Kota Tanjung Pinang (Studi Kasus Kampung Pelangi). Spirit Publik Volume 14, Nomor 2, 2019, 14(9), 103-110.

Etminan, A. (2005). Index of Refraction. Introduction to Optics, 351-377. https://doi.org/10.1007/0-387-27598-3_8

Hadiningrat, M. S. (2020). Edukasi Pembangkit Listrik Tenaga Surya Buatan "Integrated Solar Panel-Sensitized Solar Cell" Bagi Madrasah Aliyah NU Lekok dan Masyarakat Dusun Semongkrong, Pasinan, Pasuruan. Jurnal Abdimas Berdaya: Jurnal Pembelajaran, Pemberdayaan Dan Pengabdian Masyarakat, 3(02), 92. https://doi.org/10.30736/jab.v3i02.59

Irwandi, E., Sabana, S., Kusmara, A. R., \& Sanjaya, T. (2020). RESPON WARGA TERHADAP PERUBAHAN VISUAL. ANDHARUPA: Jurnal Desain Komunikasi Visual \& Multimedia, 06(02), 187-203.

Kompasiana. (2010). Bumi Perkemahan Bedengan, Cocok untuk Sarana Edukasi.

Mihas, P. (2008). Developing ideas of refraction, lenses and rainbow through the use of historical resources. Science and Education, 17(7), 751-777. https://doi.org/10.1007/s11191-006-9044-8

Rudi. (2020). Bumi Pelangi Jalaksana, Lukisan Pelangi di Kaki Ciremai. 